\title{
Sedimentary formation waters as potential low-impact lithium resources
}

\author{
ELZA DUGAMIN ${ }^{1}$, ANTONIN RICHARD ${ }^{2}$, MICHEL \\ CATHELINEAU $^{1}$, MARIE-CHRISTINE BOIRON ${ }^{1}$, FRANK \\ DESPINOIS $^{3}$ AND ANNE BRISSET ${ }^{3}$ \\ ${ }^{1}$ Université de Lorraine - CNRS - CREGU - GeoRessources \\ Laboratory \\ ${ }^{2}$ Université de Lorraine - CNRS - CREGU - GeoRessources \\ ${ }^{3}$ Centre Scientifique et Technique Jean Féger - Total \\ Presenting Author: elza.dugamin@univ-lorraine.fr
}

Electric cars will require to increase the production of lithium dramatically. However, conventional hard rock and salar mining are facing environmental and social concern worldwide. Therefore alternative low-impact Li resources may help meeting the global demand. As sedimentary formation waters are commonly extracted for geothermal energy production [1] or as by-products of oil and gas extraction [2] and $\mathrm{CO}_{2}$ storage [3], extracting $\mathrm{Li}$ would not cause significant additional impact on deep sedimentary aquifers. Here we provide a global overview of Li concentration in sedimentary formation waters from 37 worldwide sedimentary basins based on available data from the literature. About 1400 analyses of sedimentary formation waters and the following parameters were considered: $\mathrm{Li}$ concentration, total dissolved solids (TDS), $\mathrm{Mg} / \mathrm{Li}$ mass ratio, temperature, depth, age and lithology of the aquifer and geodynamic context. Li concentration shows no overall correlation with depth and temperature although minimum expected $\mathrm{Li}$ concentration increases with depth and temperature. Li concentration shows a positive correlation with TDS and is frequently above $100 \mathrm{mg} . \mathrm{l}^{-1}$ in sedimentary formation brines (i.e. TDS $>10^{5} \mathrm{mg} \cdot \mathrm{l}^{-1}$ ), as in currently mined salars brines [4]. High Li concentration may be found in both siliciclastic and carbonate ( \pm evaporite) reservoirs. $\mathrm{Mg} / \mathrm{Li}$ ratio is highly variable $\left(10^{-1}\right.$ to $\left.10^{4}\right)$ and compatible with currently economically valuable $\mathrm{Li}$ extraction for about $15 \%$ of the available data (i.e. $\mathrm{Mg} / \mathrm{Li}<10$ ). Further calculation show that the amount of lithium in some of the considered aquifers may compare with the annual $\mathrm{Li}$ demand by 2028 [5]. Therefore, Li from sedimentary formation waters should be regarded as potential major low-impact resources of Li for the next decades.

[1] Pauwels, Fouillac \& Brach (1989), BRGM, 89, SGN, 229, EEE, IRG.

[2] Carpenter, Trout, \& Pickett (1974), Economic Geology 69, 1191-1206.

[3] Birkholzer, Zhou \& Tsang (2009), International journal of greenhouse gas control 3, 181-194.

[4] Lopez Steinmetz, Salvi, Gabriela Garcia, Arnold, Béziat, Franco, Cordoba \& Caffe (2018), Journal of Geochemical Exploration 190, 26-38.

[5] Bibienne, Magnan, Rupp \& Laroche (2020), Elements 16, 265-270. 